\title{
Review of HIV Interventions among Young and Adolescent Key Populations in Low to Middle Income Countries
}

\author{
Devika Mehra $^{1 *}$, Tina Khanna ${ }^{2}$, Jagannnath Behera ${ }^{2}$ and Sunil Mehra ${ }^{2}$
}

${ }^{1}$ Medeon Science Park, Malmö, Sweden

${ }^{2}$ MAMTA Health Institute for Mother and Child, New Delhi, India

\begin{abstract}
Background: Globally, Young key populations (age 10-24) (YKPs) are more at risk to HIV infection and are disproportionately infected by HIV. There is a pressing need for evidence on how best to implement effective interventions for young key populations.
\end{abstract}

Objective: The overall aim was to conduct a systematic review of interventions to summarize the data on effectiveness of interventions in low and middle income countries among young key populations.

Method: We conducted a review of the evidence on interventions designed to increase adolescents and young people's access to services for reducing their HIV risk. We focused specifically on the young key populations from low to middle income countries. We searched PubMed, Medline and Cochrane databases using MesH terms to identify peer-reviewed articles. We included studies with designs such as randomized control trails (RCT), clustered randomized trails, quasi experimental, prospective observational and studies that measured outcomes pre and post an intervention. We identified a total of 10 studies that were included in the review based on certain inclusion and exclusion criteria.

Results: Among the interventions designed for young people, community based interventions driven by peer led approach and mobile based interventions were effective in engaging with these hard to reach populations. Structural interventions focusing on stigma and psychosocial component can positively impact important HIV-related outcomes. HIV screening needs to be integrated in programs and policy with intimate partner violence. The evidence on PreP is mixed and needs more systematic investigation.

Conclusion: Combinations of prevention packages that include behavioural, structural and biological interventions are needed for young key populations to prevent new HIV infections. These interventions with proven effectiveness should be included in all HIV prevention programming for young people.

Keywords: Key populations; HIV; Young; LMICs

\section{Introduction}

Globally young people face a high burden of HIV infections. It is estimated that $39 \%$ of new infections occur among adolescents annually, despite the global declines in HIV mortality among adults [1]. HIV-related deaths among young people have increased by $50 \%$ between 2005 and 2012 [2]. HIV risk and prevalence is not uniform in the key population which is defined as sex workers, injecting drug users (IDUs), men having sex with men (MSM) and transgender (TG). These key populations have a higher risk of HIV infection than the general population [3-5]. It is estimated that up to $50 \%$ of new infections occur among key populations annually [2]. Data on the size of adolescent key populations is scarce, particularly in the regions where the epidemic is concentrated.

The regions with the highest number of HIV positive adolescents are in Sub-Saharan Africa and South Asia. Of the 2.1 million adolescents (11-19 years) who are infected with HIV, about 1.3 million (62\%) live in Eastern and Southern Africa [6,7]. It is estimated that $95 \%$ of new infections among adolescents in Asia are among key populations such as people who inject drugs (PWID), men having sex with men (MSM) and sex workers [8] and $70 \%$ of all individuals who inject drugs are under the age of 25 [9]. This can be supported by empirical evidence that key populations and their sexual partners account for a high proportion of new HIV infections in countries such as Dominican Republic 47\%, Kenya 33\%, Morocco 80\%, Mozambique 27.5\%, Nigeria $51 \%$, Peru 65\% [10].
Young key populations are not adequately reached with appropriate and acceptable HIV prevention and treatment services due to stigma and discrimination. Many barriers limit their access to essential services or exclude them from formal health services altogether [11]. Additionally, most health services are not designed to care and address the needs of adolescents/young people and key populations. Therefore, may lack the sensitivity required to work with these populations.

There is evidence that reduction in HIV incidence can be achieved if a combination of interventions are implemented which include biological, behavioral as well as components that address social, economic and other structural factors that influence HIV prevention and transmission $[12,13]$ with specific attention given to key populations. The review focuses on interventions in low to middle income countries that address adolescent key populations.

*Corresponding author: Devika Mehra, Public Health Consultant, Medon Science Park, Per Albin Hanssons väg 41, 20502 Malmö, Sweden; Tel: 46-700663385 E-mail: 21.devika@gmail.com

Received December 11, 2017; Accepted December 19, 2017; Published December 26, 2017

Citation: Mehra D, Khanna T, Behera J, Mehra S (2017) Review of HIV Interventions among Young and Adolescent Key Populations in Low to Middle Income Countries. J AIDS Clin Res 8: 751. doi: 10.4172/2155-6113.1000751

Copyright: $\odot 2017$ Mehra D, et al. This is an open-access article distributed under the terms of the Creative Commons Attribution License, which permits unrestricted use, distribution, and reproduction in any medium, provided the original author and source are credited. 


\section{Methodology}

\section{Search strategy}

A systematic search of published literature in peer reviewed journals was undertaken for conducting this review. Scientific databases were searched such as PubMed and Medline. We also searched Google and Google scholar for investigating into the grey literature available online. We searched for individual intervention studies and systematic reviews that link HIV and sexual and reproductive health (SRH) among key populations in Sub-Saharan Africa and South East Asia. There are a large number of interventions in research that affect HIV prevention and treatment but very few that focused on adolescents in particular. The MeSH terms used were: HIV, intervention studies, key populations, most at risk, program evaluation, low and/or middle income countries, adolescents and young people. The detailed search strategy has been given below:

• (("intervention") OR ("adolescent") OR ("young people") OR ("africa") OR ("low to middle income countries") OR ("key populations") OR ("HIV") OR ("MSM") OR ("IDU") OR ("sex workers") OR ("most at risk") OR ("transgender")OR ("female sex workers") OR ("truck drivers") OR ("evaluation")) all

- ((intervention) AND (adolescent) OR (young people) OR (africa) OR (low to middle income countries) OR (key populations) OR (HIV) OR (MSM) OR (IDU) OR (sex workers) OR (most at risk) OR (transgender) OR (female sex workers) OR (truck drivers) OR (evaluation)) all [all]

- ((intervention studies) OR (evaluation) (HIV) OR (key populations))

- (Evaluation) AND (adolescent) AND (key populations) AND (HIV)

- (HIV) AND (Community interventions) AND (key populations)

\section{Eligibility criteria}

- PICO model: (Population, exposure/Intervention, comparator/ control and Outcome). If all the components were not available in the abstract, then the full text of the articles were referred for details.
- Types of articles: We included studies from peer reviewed journals and grey literature in the form of reports. We also reviewed some systematic reviews to get an overview of the situation.

- Study participants: We tried to focus on adolescents and young people but due to limited published papers we also included vulnerable groups that were beyond the age group.

- Outcome measure: Knowledge and attitude, behavioral and biological outcomes related to HIV prevention.

- Geographical coverage: The focus of the review was on studies from Sub-Saharan Africa and South East Asia. Reviews from high income countries were not included in this review.

- Date of publication: articles and literature published from 2005-2015.

\section{Exclusion criteria}

- Articles and reports not published in English.

- Citations without an abstract.

- Studies with a weak impact evaluation design.

\section{Screening}

This process involved three stages: screening of the titles, abstracts and full texts. At the first level we used MeSH terms and filters (period of publication, language and age) to narrow down the titles. For screening the interventions related to HIV/SRH and its link with key populations. At the second level, the abstracts were read to assess if they met the inclusion and exclusion criteria. The abstracts that did not meet the inclusion criteria were excluded. If some of the abstracts did not clearly define the criteria's of the PICO model then full texts of the articles were screened to access if they should be included or excluded. After which we narrowed down on the final list of abstracts which could be included (Figure 1).

\section{Results}

This review paper after the search included 10 peer reviewed articles. The detailed analysis of the articles is mentioned in the Table 1.

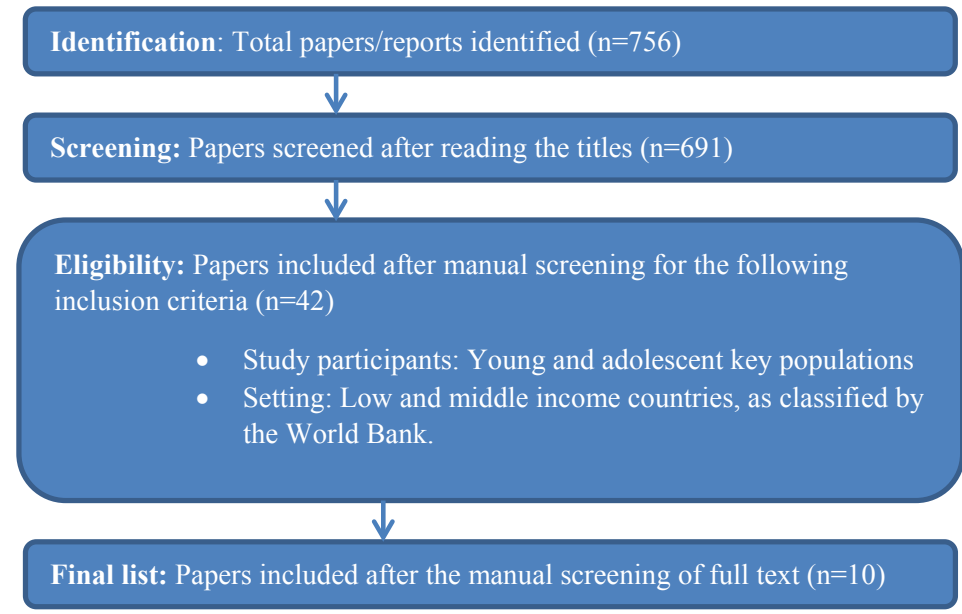

Figure 1: Flow chart of the search strategy. 
Citation: Mehra D, Khanna T, Behera J, Mehra S (2017) Review of HIV Interventions among Young and Adolescent Key Populations in Low to Middle Income Countries. J AIDS Clin Res 8: 751. doi: 10.4172/2155-6113.1000751

Page 3 of 8

\begin{tabular}{|c|c|c|c|c|c|c|c|}
\hline $\begin{array}{l}\text { S. } \\
\text { No }\end{array}$ & $\begin{array}{l}\text { Project (Author } \\
\text { [Ref no.]) and } \\
\text { Country }\end{array}$ & $\begin{array}{c}\text { Target } \\
\text { population(s) }\end{array}$ & Objective & Study Design & $\begin{array}{l}\text { Intervention } \\
\text { 1. School } \\
\text { 2. Health facility } \\
\text { 3. Community }\end{array}$ & Main Findings & $\begin{array}{l}\text { Outcomes } \\
\text { 1. Knowledge and } \\
\text { attitudinal } \\
\text { 2. Behavioral } \\
\text { 3. Biological }\end{array}$ \\
\hline 1. & $\begin{array}{c}\text { Psychological } \\
\text { and behavioural } \\
\text { Intervention } \\
\text { (Thurman et al. } \\
\text { [16]) } \\
\text { South Africa }\end{array}$ & $\begin{array}{l}\text { Adolescents } \\
\text { (14-17 years) } \\
\text { HIV infected } \\
\text { children } \\
\text { including } \\
\text { those who } \\
\text { have lost a } \\
\text { parent/parents } \\
\text { (orphans) } \\
\text { or are living } \\
\text { with someone } \\
\text { chronically ill }\end{array}$ & $\begin{array}{c}\text { To provide } \\
\text { psychological } \\
\text { and behavioural } \\
\text { interventions for } \\
\text { reducing HIV } \\
\text { among orphan } \\
\text { and vulnerable } \\
\text { adolescents in } \\
\text { South Africa }\end{array}$ & $\begin{array}{c}\text { Cluster } \\
\text { randomised } \\
\text { control trial } \\
(\mathrm{RCT}) \text { with } \\
\text { a four group } \\
\text { factorial } \\
\text { design intent } \\
\text { to treat } \\
\text { analysis }\end{array}$ & $\begin{array}{l}\text { 1. NA } \\
\text { 2. First intervention was } \\
\text { Interpersonal psychotherapy groups } \\
\text { (IPTG) - } 16 \text { weekly } 90 \text { min group } \\
\text { sessions by a trained lay adult } \\
\text { community facilitator to participant } \\
\text { on opportunities to learn and } \\
\text { practice inter-personal skills for } \\
\text { resolving distress and to facilitate } \\
\text { provision of emotional support } \\
\text { among group members through } \\
\text { techniques like problem solving and } \\
\text { identifying people who are important } \\
\text { in their lives, etc. } \\
\text { - Second intervention was called } \\
\text { Vutshilo which was curriculum } \\
\text { based behavioural intervention - } 13 \\
\text { weekly } 60 \text { min sessions on (alcohol, } \\
\text { substance abuse, crime, Sexual } \\
\text { violence, HIV, sexual relationships, } \\
\text { condom use and transactional sex). } \\
\text { Guided by a trained young facilitator } \\
\text { to engage in critical reflection on } \\
\text { these topics with fictional characters } \\
\text { and challenge themselves in similar } \\
\text { situations. The intervention helped } \\
\text { in social learning through reflection } \\
\text { and thinking through their choices } \\
\text { and consequences. } \\
\text { 3. Home visits by volunteers who } \\
\text { addressed economic security of } \\
\text { beneficiaries, support academic } \\
\text { achievement and provide referrals } \\
\text { to health care and other social } \\
\text { services. }\end{array}$ & $\begin{array}{l}\text { - Effect of both the } \\
\text { interventions individually did } \\
\text { not show a significant effect. } \\
\text { - Both the interventions } \\
\text { together led to risk reduction } \\
\text { behaviours, but the outcomes } \\
\text { varied by gender: boys } \\
\text { reported fewer risky sexual } \\
\text { partnerships }(\beta=-0.48, \\
p=0.05) \text { and girls reported } \\
\text { more consistent condom use } \\
(\beta=1.37, p=0.02) \text {. }\end{array}$ & $\begin{array}{l}\text { 1. Increase in } \\
\text { knowledge and } \\
\text { attitudes towards } \\
\text { consistent condom use } \\
\text { 2. Consistent condom } \\
\text { use among girls - } \\
\text { Reduction in sexual } \\
\text { partnerships among } \\
\text { boys } \\
\text { 3. NA }\end{array}$ \\
\hline 2. & $\begin{array}{l}\text { Ithubalethu Project } \\
\text { (Carney et al. [19]) } \\
\text { South Africa }\end{array}$ & $\begin{array}{c}16 \text { years } \\
\text { or older } \\
\text { Median age } \\
\text { (26 years), } \\
\text { Female sex } \\
\text { workers } \\
\text { (FSW) }\end{array}$ & $\begin{array}{l}\text { The purpose } \\
\text { of this study } \\
\text { was to evaluate } \\
\text { the effect of an } \\
\text { HIV prevention } \\
\text { intervention } \\
\text { for FSWs in } \\
\text { Durban, South } \\
\text { Africa }\end{array}$ & $\begin{array}{l}\text { Before and } \\
\text { after Cross- } \\
\text { sectional }\end{array}$ & $\begin{array}{l}\text { 1. NA } \\
\text { 2. NA } \\
\text { 3. Inthbalenthu project is a part of } \\
\text { a broader project Lifeline Durban } \\
\text { that was on Rapid Assessment } \\
\text { of Drug use and Sexual HIV risk } \\
\text { patterns. Its outreach workers and } \\
\text { peer educators were recruited and } \\
\text { trained on a local adaptation of a } \\
\text { community outreach model by World } \\
\text { Health Organization (WHO). } \\
\text { - Two Focused group discussions } \\
\text { (FDGs) with FSWs and two key } \\
\text { informants were conducted with } \\
\text { appropriate service providers. } \\
\text { - Twenty out-reach workers (ORW) } \\
\text { some were previous FSWs were } \\
\text { selected and given five day training. } \\
\text { - Additional } 23 \text { outreach workers } \\
\text { were also engaged to provide } \\
\text { services. } \\
\text { - Intervention with the trained } \\
\text { FSW participants completed a } \\
\text { personalised HIV risk reduction } \\
\text { plan: a) On substance use and HIV } \\
\text { risk reduction planning. } \\
\text { b) HIV counselling and testing } \\
\text { - Referrals to drug treatment HIVI } \\
\text { STI care and other social services. } \\
\text { - FSWs were also provided with } \\
\text { counselling and personal growth } \\
\text { courses and skill development } \\
\text { training. } \\
\text { - ORWs also had one follow up } \\
\text { contact with participants to measure } \\
\text { the risk behaviours. }\end{array}$ & $\begin{array}{c}\text { - There was a significant } \\
\text { decrease in the number of } \\
\text { sexual partners ( } z=-16.05, \\
p<0.001 \text { ), number of times } \\
\text { FSWs engaged in vaginal sex } \\
\text { ( } z=-8.07, p<0.001) \text {. } \\
\text { - Use of cocaine and ecstasy } \\
\text { decreased while over-the } \\
\text { counter and prescription } \\
\text { drugs increased. } \\
\text {-But no significant decrease in } \\
\text { alcohol, heroin and cannabis. } \\
\text {-The overall use of drugs } \\
\text { on a daily basis decreased } \\
\text { dramatically from } 88 \%-22 \% \\
\text { after the intervention. }\end{array}$ & $\begin{array}{l}\text { 1. Increase in } \\
\text { knowledge and } \\
\text { attitudes on substance } \\
\text { use } \\
\text { 2. Decrease in multiple } \\
\text { sexual partners and } \\
\text { substance use } \\
\text { 3. NA } \\
\end{array}$ \\
\hline
\end{tabular}




\begin{tabular}{|c|c|c|c|c|c|c|c|}
\hline 3. & $\begin{array}{l}\text { (Choopanya et al. } \\
\text { [13]) } \\
\text { Thailand, Bangkok }\end{array}$ & $\begin{array}{l}\text { PWID (People } \\
\text { who inject } \\
\text { drugs) } \\
\text { (Median age } \\
\text { is } 31 \text { years } \\
\text { (20-60 years) } \\
\text { who were HIV } \\
\text { negative }\end{array}$ & $\begin{array}{l}\text { To assess } \\
\text { whether daily } \\
\text { oral use of } \\
\text { Antiretroviral } \\
\text { prophylaxis } \\
\text { (Tenofovir) can } \\
\text { reduce HIV } \\
\text { transmission in } \\
\text { injecting drug } \\
\text { users }\end{array}$ & $\begin{array}{l}\text { Randomized } \\
\text { control trial, } \\
\text { TVD Placebo }\end{array}$ & $\begin{array}{c}\text { 1. NA } \\
\text { 2. The clinics offered HIV } \\
\text { counselling and testing, risk } \\
\text { reduction, methadone treatment, } \\
\text { condoms and clean bleach to clean } \\
\text { injection equipment was given in } 17 \\
\text { drug treatment clinics in Bangkok. } \\
\text { 3. NA }\end{array}$ & $\begin{array}{c}\text { - There was a } 48.9 \% \\
\text { reduction in HIV incidence } \\
\text { (95\% Cl 6-72.2; } p=0.01) \\
\text { - The occurrence of adverse } \\
\text { events was the same between } \\
\text { the two groups ( } p=0.35 \text { ). } \\
\text { - Nausea was more common } \\
\text { in participants in the tenofovir } \\
\text { group than in the placebo } \\
\text { group ( } p=0.002) .\end{array}$ & $\begin{array}{l}\text { 1. NA } \\
\text { 2. NA } \\
\text { 3. Reduction in HIV } \\
\text { incidence }\end{array}$ \\
\hline 4. & $\begin{array}{c}\text { (Vu Thuong et al. } \\
{[21] \text { ) }} \\
\text { Vietnam }\end{array}$ & $\begin{array}{c}\text { Female sex } \\
\text { workers }(60 \% \\
\text { between } 20- \\
29 \text { years) }\end{array}$ & $\begin{array}{l}\text { To determine } \\
\text { changes in the } \\
\text { prevalence } \\
\text { of sexually } \\
\text { transmitted } \\
\text { infection (STI)/ } \\
\text { HIV in female } \\
\text { sex workers } \\
\text { (FSWs) after } \\
\text { a community } \\
\text { HIV prevention } \\
\text { intervention } \\
\text { project in } \\
\text { five border } \\
\text { provinces of } \\
\text { Vietnam }\end{array}$ & $\begin{array}{l}\text { Longitudinal } \\
\text { study design }\end{array}$ & $\begin{array}{l}\text { 1.NA } \\
\text { 2. Care and management of } \\
\text { STIs facilities for diagnosis were } \\
\text { strengthened by improving health } \\
\text { care provider skills through training } \\
\text { and provision of STI diagnostic } \\
\text { equipment. } \\
\text {-Each province set up their mobile } \\
\text { teams to provide STI care in settings } \\
\text { that FSWs were comfortable with } \\
\text { including their place of work. } \\
\text { 3. Behaviour change communication } \\
\text { activities for host communities and } \\
\text { mobile populations were delivered } \\
\text { through peer educators to do } \\
\text { advocacy on HIV/STI messages and } \\
\text { promote health seeking behaviour. } \\
\text {-Condom promotion using social } \\
\text { marketing was done at commercial } \\
\text { places like tea shops, pharmacies, } \\
\text { beer outlets etc. Transport hot spots } \\
\text { and construction sites received } \\
\text { special attention. }\end{array}$ & $\begin{array}{c}\text { - Reduction in gonorrhoea } \\
\text { infection from } 10.7 \% \text { to } 2.9 \% \\
\text { and in Chlamydia trachomatis } \\
\text { from } 11.9 \% \text { to } 9.1 \% \text { in FSWs. } \\
\text { - HIV declined from } 4.5 \% \text { to } \\
3.6 \% \text { and HSV } 2 \text { antibodies } \\
27.7 \%-24.9 \% \text {. } \\
\text { - Significant decrease in GC } \\
\text { and/or CT OR= } 0.46(0.33- \\
0.65) \text { and GC alone was } \\
\text { OR=0.22 (0.13-0.37) and } \\
\text { the overall prevalence of } \\
\text { syphilis increased significantly } \\
\text { OR=1.55 (1.11-2.17). } \\
\end{array}$ & $\begin{array}{l}\text { 1. Increase in } \\
\text { awareness of STIs and } \\
\text { condoms } \\
\text { 2. Increase in use of } \\
\text { condoms } \\
\text { 3. Decline in the } \\
\text { prevalence of STIs }\end{array}$ \\
\hline 5. & $\begin{array}{c}\text { (Charurat et al. [22]) } \\
\text { Nigeria }\end{array}$ & \begin{tabular}{|} 
MSM, 16 \\
years and \\
older (majority \\
of the \\
participants \\
were younger \\
than 25 years)
\end{tabular} & \begin{tabular}{|c|} 
To test the \\
acceptability \\
of treatment \\
as prevention \\
(TasP) strategy \\
among HIV \\
infected MSMs \\
(men having sex \\
with men)
\end{tabular} & Pre-Post test & $\begin{array}{l}\text { 1. NA } \\
\text { 2. HIV testing and counseling was } \\
\text { conducted of all the participants. } \\
\text { - Every three months follow up } \\
\text { visits. } \\
\text { - HIV positive participants went } \\
\text { through clinical and laboratory } \\
\text { evaluation including CD4 counts } \\
\text { and HIV viral load, immediate three } \\
\text { weekly sessions of ART preparation, } \\
\text { then ART initiation using treatment } \\
\text { as prevention (TasP) strategy } \\
\text { irrespective of the CD4 count. } \\
\text { 3. NA }\end{array}$ & $\begin{array}{c}\text { - Increase in the number } \\
\text { of cases that were on ART } \\
\text { after being a part of the TasP } \\
\text { strategy of this study. } \\
\text { - Compared with MSM who } \\
\text { did not engage in TasP, those } \\
\text { who engaged had significantly } \\
\text { lower mean CD4 count } \\
\text { ( } p=0.001 \text { ), were more likely } \\
\text { to be Christian ( } p=0.01 \text { ), had } \\
\text { disclosed being MSM to family } \\
\text { ( } p=0.02 \text { ) or to the health care } \\
\text { providers ( } p=0.02) \text {. } \\
\text { - Being engaged in TasP } \\
p<0.001 \text { and on ART } \\
p<0.001 \text { was associated with } \\
\text { decreased risk of loss to } \\
\text { follow up. }\end{array}$ & $\begin{array}{l}\text { 1. NA } \\
\text { 2. Uptake of HIV } \\
\text { testing } \\
\text { 3. Increase in } \\
\text { participants on ART } \\
\text { treatment }\end{array}$ \\
\hline 6. & $\begin{array}{c}\text { Avahan } \\
\text { (Ramanathan et } \\
\text { al. [20]) } \\
\text { India }\end{array}$ & $\begin{array}{l}\text { MSM and } \\
\text { Transgender } \\
\text { Round } 1 \\
\text { Mean age } \\
\text { (25.7 years) } \\
\text { and Round } \\
2 \text { Mean age } \\
\text { (24.2 years) }\end{array}$ & $\begin{array}{l}\text { To assess } \\
\text { the coverage, } \\
\text { changes in } \\
\text { condom use } \\
\text { and prevalence } \\
\text { of other STls } \\
\text { among high } \\
\text { risk MSMs and } \\
\text { transgender }\end{array}$ & $\begin{array}{l}\text { Avhan's } \\
\text { computerised } \\
\text { Management } \\
\text { Information } \\
\text { system, } \\
\text { two rounds } \\
\text { of cross } \\
\text { sectional } \\
\text { surveys called } \\
\text { Integrated } \\
\text { Behavioural } \\
\text { Biological } \\
\text { Assessment } \\
\text { (IBBA) and } \\
\text { the program } \\
\text { supported } \\
\text { condom social } \\
\text { marketing }\end{array}$ & $\begin{array}{l}\text { 1.NA } \\
\text { 2. Avahan's STI clinics were running } \\
\text { in } 15 \text { districts of India } \\
\text { 3. Advocacy and condom } \\
\text { provision by peer educators in the } \\
\text { communities }\end{array}$ & $\begin{array}{c}\text { - The condom distribution by } \\
\text { the project increased from } \\
\text { reaching } 2.7 \text { million in } 2004 \text { to } \\
15.8 \text { million in } 2008 . \\
\text { - Increase in consistent } \\
\text { condom use Adjusted odds } \\
\text { Ratio (AOR): } \\
1.90-95 \% \mathrm{Cl}(1.01-3.58) \\
\text { with regular male partners } \\
\text { compared to IBBA and round } \\
1 . \\
\text {-High risk MSM and TG } \\
\text { reported higher consistent } \\
\text { condom use with regular } \\
\text { partners AOR: } 2.46 ; \mathrm{Cl} 1.34- \\
4.52 \text { than those who were } \\
\text { unexposed. } \\
\text { - Prevalence of reactive } \\
\text { syphilis serology declined } \\
\text { significantly from } 8.8 \% \text { in } \\
\text { round } 1 \text { to } 1.1 \% \text { in round } 2 \\
\text { (p=0.001), while the observed } \\
\text { change in HIV prevalence } \\
12.3 \% \text { to } 6.3 \%, p=0.16 \text { ) was } \\
\text { insignificant. }\end{array}$ & $\begin{array}{l}\text { 1. NA } \\
\text { 2. Uptake of clients in } \\
\text { STI clinics } \\
\text { - Increase in consistent } \\
\text { condom use } \\
\text { 3. Decline in STI } \\
\text { prevalence (Syphilis) } \\
\end{array}$ \\
\hline
\end{tabular}




\begin{tabular}{|c|c|c|c|c|c|c|c|}
\hline 7. & $\begin{array}{l}\text { FEM-PrEP (Van } \\
\text { Damme et al. [17]) } \\
\text { Kenya, South } \\
\text { Africa, Tanzania }\end{array}$ & $\begin{array}{c}\text { Women } \\
\text { (Mean age } \\
24.2 \text { years) }\end{array}$ & $\begin{array}{l}\text { The primary } \\
\text { objective was } \\
\text { to assess the } \\
\text { effectiveness } \\
\text { and safety } \\
\text { of tenofovir } \\
\text { disoproxil (TDF) } \\
\text { fumarate and } \\
\text { emtricitabine } \\
\text { (FTC) in } \\
\text { preventing HIV } \\
\text { acquisition }\end{array}$ & $\begin{array}{c}\text { Double-blind, } \\
\text { placebo- } \\
\text { controlled trial }\end{array}$ & $\begin{array}{c}\text { 1. NA } \\
\text { 2. NA } \\
\text { 3. Twenty one thousand twenty HIV } \\
\text { negative women received either } \\
\text { a combination of (TDF-FTC) or } \\
\text { placebo once daily at the health } \\
\text { facility } \\
\text { - Participants also underwent rapid } \\
\text { HIV antibody testing, pregnancy } \\
\text { testing, and assessment for adverse } \\
\text { events. } \\
\text { - Participants received counseling } \\
\text { (on risk reduction, study-drug } \\
\text { adherence, and contraceptive use). } \\
\text { - Participants also received free } \\
\text { condoms, and free (or referral for) } \\
\text { effective non barrier contraception. }\end{array}$ & $\begin{array}{l}\text { - No significant relationship } \\
\text { between transactional sex } \\
\text { and HIV incidence and good } \\
\text { adherence. } \\
\text { - Less than } 40 \% \text { of the HIV } \\
\text { uninfected women had } \\
\text { evidence of recent pill use at } \\
\text { visits that were matched to } \\
\text { the HIV infection window for } \\
\text { women with seroconversion. }\end{array}$ & $\begin{array}{l}\text { 1. NA } \\
\text { 2. NA } \\
\text { 3. Prophylaxis with } \\
\text { TDF-FTC did not } \\
\text { significantly reduce the } \\
\text { rate of HIV infection } \\
\text { and was associated } \\
\text { with increased rates of } \\
\text { side effects. } \\
\text { - Despite substantial } \\
\text { counseling efforts, drug } \\
\text { adherence appeared to } \\
\text { be low. }\end{array}$ \\
\hline 8. & $\begin{array}{c}\text { Integrated } \\
\text { intimate partner } \\
\text { violence (IPV) and } \\
\text { HIV prevention } \\
\text { intervention } \\
\text { (Wagman et al. } \\
\text { [18]) } \\
\text { Uganda }\end{array}$ & $\begin{array}{c}\text { Men and } \\
\text { women aged } \\
15-49 \text { years }\end{array}$ & $\begin{array}{l}\text { The Safe } \\
\text { Homes and } \\
\text { Respect for } \\
\text { Everyone } \\
\text { (SHARE) } \\
\text { Project aimed to } \\
\text { reduce physical } \\
\text { and sexual } \\
\text { IPV and HIV } \\
\text { incidence. }\end{array}$ & $\begin{array}{l}\text { Community- } \\
\text { based cohort } \\
\text { study (census, } \\
\text { interviews, } \\
\text { and } \\
\text { serological } \\
\text { surveys) }\end{array}$ & $\begin{array}{l}\text { 1. NA } \\
\text { 2. Standard of care HIV services } \\
\text { - Screening and brief intervention } \\
\text { to promote safe HIV disclosure and } \\
\text { risk reduction in women seeking HIV } \\
\text { services. } \\
\text { 3. Community-level mobilization } \\
\text { intervention to change attitudes, } \\
\text { social norms, and behaviors related } \\
\text { to intimate partner violence }\end{array}$ & $\begin{array}{l}\text { - Reduction in HIV incidence } \\
(1.15 \text { cases per } 100 \text { person } \\
\text { years in control vs. } 0.87 \text { cases } \\
\text { per } 100 \text { person-years in } \\
\text { intervention group }\end{array}$ & $\begin{array}{l}\text { 1. High awareness and } \\
\text { attitude shift towards } \\
\text { not supporting gender } \\
\text { based violence } \\
\text { 2. Reduction in forms } \\
\text { of physical partner } \\
\text { violence towards } \\
\text { women } \\
\text { - Reduction in forced } \\
\text { sex and increased } \\
\text { disclosure of HIV } \\
\text { results } \\
\text { 3. Reduction in HIV } \\
\text { incidence }\end{array}$ \\
\hline 9. & $\begin{array}{c}\text { Microfinance } \\
\text { and Training } \\
\text { intervention (Pronyk } \\
\text { et al. [15]) } \\
\text { South Africa }\end{array}$ & $\begin{array}{c}14-35 \text { years } \\
\text { young women }\end{array}$ & $\begin{array}{l}\text { To assess a } \\
\text { combined effect } \\
\text { of microfinance } \\
\text { and training } \\
\text { intervention } \\
\text { on HIV risk } \\
\text { behaviour } \\
\text { among } \\
\text { young female } \\
\text { participants } \\
\text { in rural South } \\
\text { Africa }\end{array}$ & $\begin{array}{c}\text { Cluster } \\
\text { randomized } \\
\text { trial }\end{array}$ & $\begin{array}{c}\text { 1. NA } \\
\text { 2. NA } \\
\text { 3. The intervention consisted of two } \\
\text { components. } \\
\text { The first was group based } \\
\text { microfinance, in which groups of five } \\
\text { women received loans to establish } \\
\text { small businesses and generating } \\
\text { income. } \\
\text { The second component consisted } \\
\text { of a gender and HIV training } \\
\text { curriculum, which was integrated } \\
\text { into establishing meetings of } 40 \\
\text { women that took place for every } 2 \\
\text { weeks for } 1 \text { year. }\end{array}$ & $\begin{array}{c}\text { 1. Young females had } \\
\text { higher levels of HIV-related } \\
\text { communication (adjusted risk } \\
\text { ratio } 1.46,95 \% \mathrm{CI} 1.01-2.12 \text { ) } \\
\text { in the intervention area than } \\
\text { control area } \\
\text { 2. More \% of young women } \\
\text { were likely to have accessed } \\
\text { voluntary counselling and } \\
\text { testing (ARR 1.64, 95\% } \\
\text { confidence interval 1.06-2.56) } \\
\text { in the intervention area than } \\
\text { control area } \\
\text { 3. Young women were less } \\
\text { likely to have had unprotected } \\
\text { sex at last intercourse with } \\
\text { a non-spousal partner (ARR } \\
0.76,95 \% \text { Cl 0.60-0.96) } \\
\text { in the intervention area as } \\
\text { compared to control area }\end{array}$ & $\begin{array}{l}\text { 1. Young girls had } \\
\text { better knowledge on } \\
\text { HIV and treatment } \\
\text { services available in } \\
\text { the intervention area } \\
\text { as compared to the } \\
\text { control area. } \\
\text { 2. More proportion } \\
\text { of young women } \\
\text { accessed counselling } \\
\text { and treatment services } \\
\text { in the intervention area } \\
\text { than control area. } \\
\end{array}$ \\
\hline 10. & $\begin{array}{c}\text { Cost-effective } \\
\text { Orphan girls } \\
\text { school intervention } \\
\text { programme (Miller } \\
\text { et al. [14]) } \\
\text { Zimbabwe }\end{array}$ & $\begin{array}{l}\text { Adolescent } \\
\text { orphans }\end{array}$ & $\begin{array}{l}\text { To assess } \\
\text { the cost- } \\
\text { effectiveness of } \\
\text { school support } \\
\text { as a structural } \\
\text { intervention to } \\
\text { prevent HIV } \\
\text { risk factors } \\
\text { among orphan } \\
\text { adolescent girls } \\
\text { in Zimbabwe }\end{array}$ & \begin{tabular}{|c|} 
Randomized \\
controlled trial
\end{tabular} & $\begin{array}{l}\text { 1. School support included fees, } \\
\text { uniforms, and school supplies such } \\
\text { as pens, etc.) } \\
\text { - In addition, female teachers at } \\
\text { each intervention primary school } \\
\text { was selected and trained by } \\
\text { research personnel as helpers } \\
\text { (approximately } 1 \text { helper to } 10 \\
\text { participants/students) to monitor } \\
\text { school attendance and intervene as } \\
\text { needed with absenteeism problems } \\
\text { and supported them in their need. } \\
\text { 2. NA } \\
\text { 3. NA }\end{array}$ & $\begin{array}{l}\text { - The intervention significantly } \\
\text { reduced early marriage; } \\
\text { increased years of schooling } \\
\text { completed, and increased } \\
\text { health-related quality of life. } \\
\text { - By reducing early marriage, } \\
\text { the evidence suggests the } \\
\text { intervention reduced HIV } \\
\text { infection. The intervention } \\
\text { yielded an estimated } \\
\text { US } \$ 1,472 \text { in societal benefits } \\
\text { and an estimated gain of } 0.36 \\
\text { QALYs per orphan supported. }\end{array}$ & $\begin{array}{l}\text { 1. NA } \\
\text { 2. Decrease in early } \\
\text { marriage, increased } \\
\text { years of schooling } \\
\text { 3. Reduction in HIV } \\
\text { infection }\end{array}$ \\
\hline
\end{tabular}

Table 1: Review of young key populations in low to middle income countries.

\section{Discussion}

\section{Population and setting}

We focused on interventions that included key populations/mostat-risk populations such as MSMs, FSWs, IDUs, orphans and women that are more vulnerable to HIV.

\section{Study designs}

This review involved an extensive research but we focused on interventions that adopted high quality study designs such as RCTs [14-19] before and after cross-sectional [20,21], longitudinal [22] and pre-post-tests [23]. 


\section{Types of interventions}

In our review we found interventions that adopted psychological and behavioral strategies [14], community based interventions with peer educators and outreach workers where FSWs were provided HIV counseling/testing and skill development [20]. The review found evidence on antiretroviral prophylaxis treatment with HIV counseling and testing [15]. There was an intervention on care \& management of STI facilities where the mobile teams provided STI services adopting behaviour change communication strategies were implemented through peer educators doing condom promotion (social marketing) [22].

There was recent evidence on HIV testing and counseling followed by Treatment as Prevention (TasP) irrespective of CD4 counts for HIV positive [23], STI clinics with condom promotion [21], ART PreP treatment for prevention for women [16]. Studies also focused on HIV testing and intervention to promote safe HIV disclosure, risk reduction and community mobilization to change norms, behaviours and attitudes for intimate partner violence [17]. Microfinance and training interventions along with gender and HIV training [18] and Cost effective orphan girl's school intervention program [19] was also found in our review.

\section{Types of outcomes}

In our review we found behavioral, knowledge/attitudinal and biological outcomes. The various types of outcomes were related to sexually transmitted infections, condom use, sexual partners, substance use, HIV incidence, HIV testing and counseling, ART treatment, drug adherence and intimate partner violence.

\section{Interventions and their effects on the outcomes}

Behavioral/community based interventions: Behavioral interventions seek to reduce the risk of HIV transmission by addressing risky behaviors. The most basic component of combination prevention that is adopted in most programs are forms of behavior change communication strategies [24]. Orphan vulnerable children are at a heightened risk of HIV therefore, it is crucial that they receive HIV education, adding interventions that address psychological health may be even more effective. Psychological distress is one of the key factors for poor sexual decision making and is a particular salient for Orphan vulnerable children (OVC) since they are at a higher risk of mental health problems $[25,26]$. We found a study that was conducted in South Africa it combined psychological and behavioural interventions which showed greater risk reduction among orphan vulnerable children. Exposure to structured group based behavioural health intervention and inter-personal psychotherapy sessions led to risk reduction behavior among boys (safe sexual partnerships) and girls (consistent condom use) [14]. This study showed that a multi-faceted approach in reducing sexual risk behaviour among vulnerable adolescents was promising for mitigating the HIV epidemic among key populations. There is scientific evidence from orphan vulnerable children in South Africa that minimal psychosocial support that is offered, due to which they face numerous challenges in public primary schools, including lack of professionals to provide guidance and counselling services, very few teachers trained in life orientation, and a lack of support from parents/guardians for OVC [27].

Community based interventions: In our review we found two interventions that were conducted on FSWs that adopted a community based approach, one of which was implemented in Vietnam that provided user friendly STI services for FSWs using mobile teams operating at multiple sites depending on local client preferences [22]. The project adopted behavior change communication strategies, condom promotion and social marketing, care and management of STI clinics which led to an increase in awareness of STIs, use of condoms and decline in the prevalence of STIs. This finding can be corroborated with other studies conducted in Burkino Faso and China which also adopted community based interventions using peer based prevention and care, educational sessions and condom promotion that reduced the HIV incidence among young FSWs [28,29]. Community empowerment, condom promotion, HIV testing and counseling (HTC) with linkage to treatment and care services, STI treatment and health education have shown to be effective interventions for sex workers, but they have not been taken to scale or adequately resourced in most parts of the world [30].

In our review we found one study that was conducted in South Africa to evaluate HIV prevention among substance using FSWs [20]. The intervention was provided by training outreach workers and consisted of a community based outreach, HIV and substance use education and information. This led to decrease in number of sexual partners; frequency of virginal sex and overall substance abuse. But, there was no decrease in taking over the counter drugs. There are very few studies that have focused on interventions with such sub-populations.

In our review we found a study that was conducted on men having sex with men and transgender that was implemented in 15 districts of India with advocacy and condom provision by peer educators in the communities [21]. This led to an increase in utilization of clients in STI clinics, increase in consistent condom use and decline in STI prevalence. Research on men having sex with men and transgender shows that an ideal combination would include effective interventions that address behavioural risk factors, PrEP uptake and adherence support as well as addressing structural barriers to prevention (including criminalization, stigma, discrimination and homophobia). There is evidence from a review of HIV interventions of young adults/adolescents which found that there were on 3 interventions that were specifically tailored to the needs of MSM/bisexual male adolescents and young adults [31]. There is limited evidence on targeted and evaluated interventions on this key population.

Another community based intervention for reducing IPV and HIV among women was implemented in Uganda [17]. It was a high impact intervention as it led to an improvement in awareness and shift in attitude towards reduction in forms of physical partner violence towards women, forced sex, increased disclosure in HIV results, reduction in HIV incidence and not supporting gender based violence. There is evidence from previous research that educational interventions have shown short term improvements in HIV related knowledge and behavioral intervention. Further, research is needed to examine brief screening, intervention and referral for HIV and IPV services within health care settings.

Biomedical interventions: The aim of biomedical prevention interventions is to reduce the risk of HIV transmission by reducing the risk of exposure or by reducing the risk associated with an exposure. Different array of interventions in biomedical prevention strategies include the use of condoms, vaccines, microbicides, penile circumcision, treatment of STIs and the use of antiretroviral drugs by HIV negative people (post-exposure prophylaxis and pre-exposure prophylaxis) and HIV positive people (effective treatment to prevent transmission). Some biomedical prevention interventions have been found to be effective, while some are not effective at reducing the risk of HIV transmission, particularly studies related to prophylaxis 
intervention. The study conducted by Van Damme et al. [16]. In our review shows that prophylaxis with tenofovir disoproxil fumarate and emtricitabine (TDF-FTC) did not significantly reduce the rate of HIV infection and was associated with increased rates of side effects, compared to the placebo group. Despite substantial counselling efforts, drug adherence appeared to be low in intervention areas and the rates of drug discontinuation because of hepatic or renal abnormalities were higher in the TDF-FTC group than in the placebo group.

In another randomised, double-blind, placebo-controlled trial conducted on IDUs in Bangkok showed that daily oral tenofovir reduced the risk of HIV infection by $48.9 \%$ in injecting drug users when provided with other HIV prevention services at drug-treatment clinics in Bangkok [15]. As in this study, findings from other preexposure prophylaxis trials showed that adherence had an important effect on efficacy. As has been reported in other trials participants in the tenofovir group reported more nausea and vomiting in the first couple of months of follow-up than did those in the placebo group $[32,33]$. When used for treatment of HIV, tenofovir is associated with small decreases in renal function $[34,35]$. This study did not find higher rates of increased creatinine or renal disease in participants randomly allocated to tenofovir. This study recommends that pre-exposure prophylaxis with tenofovir can now be considered for use as part of an HIV prevention package. PrEP could therefore offer a highly effective, time-limited primary prevention for young key populations if it is implemented in combination with other programs to increase access to health services and encourage the reliable use of PrEP while at risk of HIV exposure. Improved efforts are needed to make these interventions accessible to those who would most benefit from them and move them into practice in a way that is safe and effective. All biomedical prevention interventions should be combined with a comprehensive sexual health plan that includes regular HIV/STI testing and treatment, ongoing adherence and risk-reduction counselling to reduce the risk of HIV transmission.

Researchers have been calling for new innovations in HIV prevention for MSM. Treatment as prevention (TasP) strategy represents one such tool. Review of a study in Nigeria report findings on acceptability of TasP among HIV-infected MSM at a Trusted Community Center providing comprehensive HIV prevention and treatment services to MSM in Abuja, Nigeria. The findings show that compared to MSM who did not engage in TasP, disclosure of being MSM to health care providers remained significantly associated with uptake of TasP. Also being engaged in TasP (Relative Hazards $[\mathrm{RH}]=0.08, \mathrm{p}<0.001$ ) and on ART $(\mathrm{RH}=0.17, \mathrm{p}<0.001)$ were associated with decreased risk of loss to follow up.

Economic and social interventions: The structural interventions have the potential to address the economic and social vulnerability of women for contributing to measurable health gains, including reductions in levels of IPV and high-risk sexual behavior. It is evident that addressing women's immediate financial needs provided an important incentive for maintaining gender empowerment and focused HIV prevention program in the backward areas.

The RCT study conducted by Pronyk et al. shows that after 2 years of follow-up, when compared with controls, young participants had higher levels of HIV-related communication, were more likely to have accessed voluntary counseling and testing, and less likely to have had unprotected sex at last intercourse with a non-spousal partner [18]. Qualitative data suggests a greater acceptance of intra-household communication about HIV and sexuality. Although women noted challenges associated with acceptance of condoms by men, increased confidence and skills associated with participation in the intervention supported their introduction in sexual relationships. Another research finding has suggested that an intervention combining microfinance with a gender and HIV training curriculum can lead to improvement in household economic well-being, women's empowerment, and to reductions in levels of IPV [36]. This would further reduce the HIV risk.

Costs and benefits of various interventions during planning and evaluating HIV prevention programs are gaining importance over the years. Resources to fund these programs are limited and must be used judiciously to maximize the number of HIV infections averted. Economic evaluation studies of HIV prevention interventions can generate evidence if it was value for money. Special emphasis is given to studies dealing with interventions to reduce or avoid HIV-related risk behaviors. The cost-effectiveness through a randomized controlled trial shows that 'school support as a structural intervention to prevent HIV risk factors among Zimbabwe orphan girl adolescents gained cost per quality-adjusted life year'. The intervention significantly reduced early marriage; increased years of schooling completed and increased healthrelated quality of life. By reducing early marriage, the evidence suggests the intervention reduced HIV infection. The intervention yielded significant for societal benefits and an estimated gain of 0.36 QALYs per orphan supported.

\section{Conclusion}

This paper presents some important risks for HIV and challenges to prevention including stigma, marginalization and discrimination. It is crucial that we address structural risk factors when developing prevention packages for these targeted key populations. Further, this study highlights important findings which are crucial for key populations. The HIV interventions for orphan vulnerable children need to emphasize on psychosocial support in addition to HIV services. Peer based approach and mobile technology should be used to address hard to reach populations. HIV screening needs to be integrated in programs related to intimate partner violence for future interventions. In our review we found that there was mixed evidence on the effectiveness of PreP therefore it needs to be investigated more systematically. At a broader level we feel that combination prevention packages that include effective, acceptable and scalable behavioural, structural and biologic interventions will be needed for all key populations to prevent new HIV infections. But, for all these interventions it is important to address the critical enablers for them to access HIV testing and health services.

\section{Acknowledgment}

DM contributed to the study design, interpreting the results and drafted the manuscript. TK and JB contributed to the data analysis and in the writing of the manuscript. SM contributed to the design of the study and in providing technical comments on the manuscript. All authors have read and approved the final manuscript.

\section{Funding}

The authors have not received any funding or benefits from industry or elsewhere to conduct this study

\section{References}

1. UNAIDS 2012, UNAIDS report on the global AIDS epidemic, Geneva.

2. UNAIDS 2013, UNAIDS report on the global AIDS epidemic, Geneva.

3. Baral S, Sifakis F, Cleghorn F, Beyrer C (2007) Elevated risk for HIV infection among men who have sex with men in low and middle-income countries 2000 2006: A systematic review. PLoS Med 4: e339.

4. Herbst JH, Jacobs ED, Finlayson TJ, McKleroy VS, Neumann MS, et al. (2008) Estimating HIV prevalence and risk behaviors of transgender persons in the United States: A systematic review. AIDS Behav 12: 1-17. 
5. Baral S, Beyrer C, Muessig K, Poteat T, Wirtz AL, et al. (2012) Burden of HIV among female sex workers in low-income and middle-income countries: A systematic review and meta-analysis. Lancet Infect Dis 12: 538-549.

6. Jaspan HB, Berwick JR, Myer L, Mathews C, Flisher AJ, et al. (2006) Adolescent HIV prevalence, sexual risk, and willingness to participate in HIV vaccine trials. J Adolesc Health 39: 642-648.

7. Dunkle KL, Jewkes R, Nduna M, Jama N, Levin J, et al. (2007) Transactional sex with casual and main partners among young South African men in the rura Eastern Cape: Prevalence, predictors, and associations with gender-based violence. Soc Sci Med 65: 1235-1248.

8. Schunter BT, Cheng WS, Kendall M, Marais H (2014) Lessons learned from a review of interventions for adolescent and young key populations in Asia Pacific and opportunities for programming. J Acquir Immune Defic Syndr 66 S186-S192.

9. UNAIDS (2008) Redefining AIDS in Asia: crafting an effective response. New Delhi, India.

10. AMFAR (2013) Tackling HIVIAIDS among key populations: Essential to achieving an AIDS-free generation. Issue Brief.

11. Baggaley R, Armstrong A, Dodd Z, Ngoksin E, Krug A (2015) Young key populations and HIV: A special emphasis and consideration in the new WHO consolidated guidelines on HIV prevention, diagnosis, treatment and care for key populations. J Int AIDS Soc 18: 19438.

12. Alistar SS, Owens DK, Brandeau ML (2014) Effectiveness and cost effectiveness of oral pre-exposure prophylaxis in a portfolio of prevention programs for injection drug users in mixed HIV epidemics. PLoS One 9: e86584.

13. Baeten JM, Haberer JE, Liu AY, Sista N, et al., (2013) Preexposure prophylaxis for HIV prevention: where have we been and where are we going? J Acquir Immune Defic Syndr 63: S122-129.

14. Thurman TR, Kidman R, Carton TW, Chiroro P, et al., (2016) Psychologica and behavioral interventions to reduce HIV risk: evidence from a randomized control trial among orphaned and vulnerable adolescents in South Africa. AIDS Care 28: 8-15.

15. Choopanya K, Martin M, Suntharasamai P, Sangkum U, Mock PA, et al. (2013) Antiretroviral prophylaxis for HIV infection in injecting drug users in Bangkok Thailand (the Bangkok Tenofovir Study): A randomised, double-blind, placebocontrolled phase 3 trial. Lancet 381: 2083-2090.

16. Van Damme L, Corneli A, Ahmed K, Agot K, Lombaard J, et al. (2012) Preexposure prophylaxis for HIV infection among African women. N Engl J Med 367: 411-422.

17. Wagman JA, Gray RH, Campbell JC, Thoma M, Ndyanabo A, et al. (2015) Effectiveness of an integrated intimate partner violence and HIV prevention intervention in Rakai, Uganda: Analysis of an intervention in an existing cluster randomised cohort. Lancet Glob Health 3: e23-e33.

18. Pronyk PM, Kim JC, Abramsky T, Phetla G, Hargreaves JR, et al. (2008) A combined microfinance and training intervention can reduce HIV risk behaviour in young female participants. AIDS 22: 1659-1665.

19. Miller T, Hallfors D, Cho H, Luseno W, Waehrer G (2013) Cost-effectiveness of school support for orphan girls to prevent HIV infection in Zimbabwe. Sci 14: $503-512$

20. Carney T, Petersen Williams PM, Parry CD (2016) Ithubalethu-intervention to address drug use and sexual HIV risk patterns among female commercial sex workers in Durban, South Africa. J Psychoactive Drugs 48: 303-309.
21. Ramanathan S, Deshpande S, Gautam A, Pardeshi DB, Ramakrishnan L, et al. (2014) Increase in condom use and decline in prevalence of sexually transmitted infections among high-risk men who have sex with men and transgender persons in Maharashtra, India: Avahan, the India AIDS initiative. BMC Public Health 14: 784

22. Vu Thuong N, Van Nghia K, Phuc Hau T, Thanh Long N, Thi Bao Van C, et al (2007) Impact of a community sexually transmitted infection/HIV intervention project on female sex workers in five border provinces of Vietnam. Sex Transm Infect 83: 376-382.

23. Charurat ME, Emmanuel B, Akolo C, Keshinro B, Nowak RG, et al. (2015) Uptake of treatment as prevention for HIV and continuum of care among HIVpositive men who have sex with men in Nigeria. J Acquir Immune Defic Syndr 68: S114-S123.

24. UNAIDS (2016) The Prevention Gap Report.

25. Chi P, Li X (2013) Impact of parental HIVIAIDS on children's psychological wellbeing: A systematic review of global literature. AIDS Behav 17: 2554-2574

26. Cluver L, Gardner F (2007) The mental health of children orphaned by AIDS a review of international and southern African research. J Child Adolesc Ment Health 19: 1-17.

27. Mwoma TPJ (2015) Psychosocial support for orphans and vulnerable children in public primary schools: Challenges and intervention strategies. South Afr $J$ Educ 35: 1-9.

28. Wu Z, Rou K, Jia M, Duan S, Sullivan SG, et al., (2007) The first community based sexually transmitted disease/HIV intervention trial for female sex workers in China. AIDS 21: S89-S94.

29. Traore IT, Meda N, Hema NM, Ouedraogo D, Some F, et al. (2015) HIV prevention and care services for female sex workers: efficacy of a targeted community-based intervention in Burkina Faso. J Int AIDS Soc 18: 20088.

30. Bekker LG, Johnson L, Cowan F, Overs C, Besada D, et al. (2015) Combination HIV prevention for female sex workers: What is the evidence? Lancet 385 : 72-87.

31. Harper GW, Riplinger AJ (2013) HIV prevention interventions for adolescents and young adults: What about the needs of gay and bisexual males? AIDS Behav 17: 1082-1095.

32. Grant RM, Lama JR, Anderson PL, McMahan V, Liu AY, et al., (2010) Preexposure chemoprophylaxis for HIV prevention in men who have sex with men. N Engl J Med 363: 2587-2599.

33. Thigpen MC, Kebaabetswe PM, Paxton LA, Smith DK, Rose CE, et al., (2012) Antiretroviral preexposure prophylaxis for heterosexual HIV transmission in Botswana. N Engl J Med 367: 423-434.

34. Cooper RD, Wiebe N, Smith N, Keiser P, Naicker S, et al., (2010) Systematic review and meta-analysis: renal safety of tenofovir disoproxil fumarate in HIV infected patients. Clin Infect Dis 51: 496-505

35. Gallant JE, Winston JA, DeJesus E, Pozniak AL, Chen SS, et al., (2008) The 3 -year renal safety of a tenofovir disoproxil fumarate vs. a thymidine analoguecontaining regimen in antiretroviral-naive patients. AIDS 22: 2155-2163.

36. Kim JC, Watts $\mathrm{CH}$, Hargreaves JR, Ndhlovu LX, Phetla G, et al., (2007) Understanding the impact of a microfinance-based intervention on women's empowerment and the reduction of intimate partner violence in South Africa. Am J Public Health 97: 1794-1802. 